\title{
Sites of contestation in global fur networks
}

DOI:

10.1016/j.geoforum.2019.11.009

\section{Document Version}

Accepted author manuscript

Link to publication record in Manchester Research Explorer

\section{Citation for published version (APA):}

Kleibert, J., Hess, M., \& Mueller, F. (2020). Sites of contestation in global fur networks. Geoforum, 108, 39-48. https://doi.org/10.1016/j.geoforum.2019.11.009

\section{Published in:}

Geoforum

\section{Citing this paper}

Please note that where the full-text provided on Manchester Research Explorer is the Author Accepted Manuscript or Proof version this may differ from the final Published version. If citing, it is advised that you check and use the publisher's definitive version.

\section{General rights}

Copyright and moral rights for the publications made accessible in the Research Explorer are retained by the authors and/or other copyright owners and it is a condition of accessing publications that users recognise and abide by the legal requirements associated with these rights.

\section{Takedown policy}

If you believe that this document breaches copyright please refer to the University of Manchester's Takedown Procedures [http://man.ac.uk/04Y6Bo] or contact uml.scholarlycommunications@manchester.ac.uk providing relevant details, so we can investigate your claim.

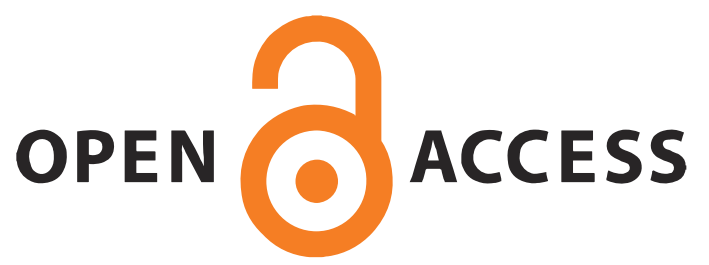




\title{
Sites of contestation in global fur networks
}

Jana M. Kleibert, Leibniz Institute for Research on Society and Space \& Humboldt University of Berlin Martin Hess, University of Manchester

Felix C. Müller, Leibniz Institute for Research on Society and Space

\section{Acknowledgements}

Jana Kleibert and Felix Müller appreciate funding by the Leibniz Association for the research project "Geographies of Dissociation: The Social Construction of Values from a Spatial Perspective" (grant number SAW-2015-IRS-1), led by Oliver Ibert. The authors wish to thank Oliver Ibert for his support throughout the entire research project and Rory Horner for valuable feedback as discussant at the AAG 2019 in Washington, D.C.

\begin{abstract}
Fur is a highly contested commodity, yet constitutes a growing global market. Global production networks of fur are premised upon the commodification of nature in the form of animal skins, which is contested by consumers and civil society groups, such as animal rights activists. While there is already a considerable body of work on ethical consumption and environmental governance and in/of GPNs, we argue that the strategies of political contestation by producers and consumers alike deserve more explicit attention. In particular, the ways in which various GPN actors struggle over valuation requires a stronger recognition of related practices of association and dissociation to establish or stabilise their respective value regimes. Our study focuses on key sites of contestation that span the global geographies of fur(-fashion) production networks: fur farms, auctions, trade fairs, design centres, whole-sale and retail shops in various countries. By analysing the political-economic, discursive and material dimensions of political contestation in fur GPNs, we aim to contribute to a Cultural Political Economy of GPNs.
\end{abstract}

Key Words: Contestation, Global Production Networks, Ethical Consumption, Dissociation, Fur

\section{Accepted for publication in Geoforum}

https://doi.org/10.1016/j.geoforum.2019.11.009 


\section{Introduction}

"The fur trade is persecution against animals. Is fur really necessary? I don't think so! Hong Kong is an international city. We should not let the trade prevail in Hong Kong." (Au Nok-hin, pro-democracy lawmaker, cited in the South China Morning Post 18 February 2019)

Global production networks (GPNs) are "contested fields" in which producers and consumers struggle over the realisation of economic and moral value(s) (Levy, 2008). The exponential growth of studies on GPNs and global value chains (GVCs) has over time broadened its focus from spatial and governance arrangements to include issues of labour and the environment, which constitute prominent moments of contestation. GPN and GVC studies have, for instance, focused on contestations around labour standards in the global South, in industries such as garments, coffee and exotic fruit (Bair and Palpacuer 2015; Arnold and Hess 2017; Alford 2018; Levy 2008; Levy et al. 2015). Moreover, recent studies on GPNs commodifying the environment, and in particular animals, have provided valuable insights into the production and circulation of commodities and the governance of value chains (Havice and Campling 2017; Baglioni and Campling 2017; Irarrázaval and Bustos-Gallardo 2019). However, these studies have largely excluded the spheres of consumption. In the case studies of tuna and salmon production networks, for instance, the focus has been on the environmental (and labour) standards in these sectors and not on the ethicalities of commodifying more-than-human-worlds (see Collard and Dempsey 2013).

Integrating the analysis of production and consumption and paying attention to the cultural and economic dimensions of value creation simultaneously has been suggested more than a decade ago as a promising avenue for investigating transnationally-organised production networks (Hudson, 2008; Hughes et al., 2008). However, in a recent article that takes stock of contemporary GPN research, Coe and Yeung (2019) stipulate that an important gap still remains around integrating the geographies of final consumption into GPN research. They suggest the 'geographies of dissociation' framework (Ibert et al., 2019) as one way to move forward in this direction (Coe and Yeung, 2019: 793). Dissociations by lead firms and brands "denote a distinct type of proactive and reactive relational work, chiefly aimed at hiding potentially problematic aspects from consumers' awareness" (Ibert et al., 2019: 44) that play a central role in the creation of symbolic value. In addition to better-known practices of associations and branding, dissociations can be mobilised by various parties to promote their values and stabilise desired valuation regimes. Value regimes do not exist independent of their social and cultural context but are created and contested through relational work that produces specific meanings to form 'ethico-political complexes' (Willmott 2010). In our case study on global fur, we focus on a particularly controversial industry, where contestations have focused less on questions of how to organise production in a fair and sustainable way, but where strong animal rights groups have pushed for a prohibition of commodifying fur under any conditions. The fundamental challenge to its very survival is thus characteristic of the global fur industry, which despite popular protests has grown over the past years.

The aim of this paper is to present a cultural political economy perspective on the different struggles around the commodification and valuation of fur at the stages of production, circulation and consumption. All three realms are important arenas in which the value(s) of fur are negotiated and challenged by a variety of actors. By investigating different processes of struggle over 'ethicality' and 
'sustainability' of global fur (fashion) production, we respond to the repeated calls in GPN research to pay more attention to consumers and civil society (Coe et al., 2008; Coe and Yeung, 2015). The current lack of studies that integrate ethical value(s) and consumers more fully into their analysis may potentially "reflect the methodological challenges of studying global production networks at the point where they fan out towards myriad individual consumers" (Coe and Yeung, 2019: 793). In this study, we suggest a methodology that focuses on particular sites of contestation to address this methodological dilemma.

The following section critically engages with questions of commodification and valuation in contemporary production systems and discusses the roles of consumers and producers in establishing and challenging value creation in GPNs through mobilising strategies of ethical consumption. Section 3 outlines the methodology deployed to analyse moments of contestation in the global fur networks, leading to our subsequent empirical analysis of contestation in the fur industry. In section 4, we analyse the geographies and practices of contestation around particular moments of global fur production networks: the sites of production, the sites of trade and intermediation, and the sites of retail and consumption. The article concludes with the contested practices and geographies of 'ethical' fur and methodological reflections.

\section{Struggling for value(s) in 'ethical' GPNs}

GVC analysis and the GPN approach share substantial common ground, insofar as they are both investigating inter-organizational networks of economic activity that link households, enterprises and states in the world economy, and thus connecting and integrating parts of disparate national and subnational territories (Henderson et al., 2002; Coe and Yeung 2015). As the formation of GPNs unfolds in the context of today's neoliberal systems of production - the capitalist imperative of markets and competition - new social and spatial divisions of labour are created in which powerful firms organize and coordinate the processes of value creation at various stages, from production through distribution to consumption. But firms and the networks they create and engage in do not exist in a vacuum. "Hence, the precise nature and articulation of GPNs are deeply influenced by the concrete sociopolitical, institutional and cultural 'places' within which they are embedded, produced and reproduced" (Coe et al. 2008: 279). This has long been recognised, and the substantial body of work that has emerged scrutinizing GPNs with regard to their social and environmental impacts (Alexander 2018; Barrientos et al. 2011; De Marchi et al. 2013; Goger 2013) is testament to that.

However, to date GPN analysis has addressed environmental and social issues largely through the lens of public and private governance, and the role of standards in achieving positive change (Nadvi 2008; Ponte 2008; Ponte, Poulsen and Lister 2017). Consequently, state regulation and in particular the selfregulation of lead firms in global value chains through private standards and codes of conduct have been at the core of this strand of research. With regard to environmental questions, Havice and Campling (2017: 296) more specifically identified three themes that run through analyses of GPNenvironment relations: i) capital-state relations and the power of lead firms in environmental governance; ii) the materiality and territoriality of natural resources, and the sustainability agendas of buyers (brands); and iii) the question of environmental upgrading and related GPN coordination. Although the literature on GPNs, standards and environmental upgrading acknowledges the role of civil society, what can be obscured by such a focus on inter-firm governance and state regulation is the role of final consumers and consumer activist groups in shaping environmental standards and 
politics (Hughes et al. 2008). In particular, acts of political contestation and political consumption which are not only aimed at addressing environmental questions with regard to the ecological conditions of producing a commodity, but which also may challenge the very rationale for production itself, deserve more explicit attention. This is particularly pertinent in GPNs that have at their core the commodification of living beings, as in our case of fur production where exchange value is created and profit is extracted in the first place from sites of production that engage in farming animals.

In order to create, sustain and appropriate exchange value, producers need to convince consumers of the use value as well as the symbolic value of fur fashion, and increasingly demonstrate their ethical credentials in terms of animal welfare and environmental sustainability. The 'geographies of dissociation' framework (Ibert et al., 2019) outlines how symbolic value creation relies on dialectical practices of association and dissociation (see Bair, 2019). Thus, companies and brands need to develop a set of positive associations between their product and other entities, such as fur being a 'natural', sustainable product, or fur being a fashionable item endorsed by celebrities. At the same time, brands need to "dissociate" themselves from problematic aspects of their production networks by obscuring negative links between their products and other entities (Ibert et al., 2019), such as the conditions in which farmed fur animals are held or they ways in which they are killed. Ethical consumers and civil society organisations, in contrast, aim to highlight the negative links between products and other entities through establishing counter-associations that shed light on the 'dark' places and make visible the 'missing' links in GPNs, for instance by documenting and visualising the conditions of live animals in fur farms, or shaming celebrities for their endorsement of what is seen as cruelty against animals. Consequently, consumers and NGOs directly challenge the use value of fur as unethical given the existing alternatives in clothing and fashion. The struggle over valuating 'nature' thus involves ongoing relational work by producers to maintain commodification while ethical consumers pursue the goal of de-commodifying fur not only by ignoring what was or might again become its exchange value (Sayer 2003) refusing to buy the product any more, but also by attempting to legally ban production outright. In other words, consumer activists and fur producers engage in an ongoing struggle over the value of nature, what determines value, and what should and should not be considered valuable (Kay and Kenney-Lazar 2018.)

Traditionally, the spatial analysis of GVCs and GPNs has been more concerned with scrutinizing the producer-related parts of value chains and - despite notable exceptions - often tended to neglect the important role acts of consumption play in the process of commodification and value creation. Hughes et al. (2008: 349) argued that the academic literature on GVCs and GPNs - while recognising the role of commodity circulation in linking production, distribution and consumption - has not sufficiently mobilised a 'commodity cultures' approach as developed in cultural geography (Cook and Crang 1996). In their conceptualisation of the role of consumption in GPNs they highlight "(i) the knowledgeable and networked practices through which notions of ethics are mobilized to inform the corporate coordination of GPNs; and (ii) the embeddedness of these networked practices and resulting forms of responsible governance in particular spaces of ethical campaigning" (Hughes et al. 2008: 347). This represented an important step towards integrating the role of consumption and consumers more explicitly into GPN research by demonstrating how corporate practices of ethical production become incorporated into the governance of GPNs partly as a reaction to and result of ethical campaigning by consumers. Since then, efforts have been made to integrate consumers in the global South (Crang and Hughes, 2015; Hughes et al., 2015) into GPN studies. The broader agenda set out in these earlier studies, however, has not been fully taken on. 
There is now little doubt that ethical consumption has become a major arena for civil society actors to try and individually or collectively effect change in production systems and practices, and influence state regulation as well as corporate social responsibility (CSR) initiatives, also beyond the Global North (Crang and Hughes, 2015; Hughes et al. 2015). By putting ethically problematic aspects of products, production and labour processes, and value distribution under the spotlight, consumer activism provides a route to politicize unfair and unsustainable models of production. Yet, despite some success, many of the social and environmental problems linked to GPN-orchestrated commodity production persist, indicating the limitations of conscientious consumerism as a transformative force (Bartley et al. 2015; see also Richey and Ponte 2011; Richey 2019). In their analysis of consumers' role in shaping global production and the meaning of standards, Bartley et al. (2015) have identified several constraints and contradictions of political consumption and contestation. First, using ethical consumption as a lever to challenge existing production systems rests on political subjectivities and affords wealthier consumers more influence to decide which problems to prioritize (for instance, concerns about environmental sustainability rather than social justice). Second, and related, many forms of conscientious consumerism may thus reinforce class and status differences by imposing particular forms of moral valuation and thus defining what constitutes 'good' consumers while shaming others for their moral failures. This problem becomes even more pronounced if ethical forms of consumption do not also address wider questions of over-consumption which in effect helps to stabilise capitalist modes of (over-)production. Third, by focusing on working with the market to address problems (for instance through fair trade initiatives), other strategies to achieve social and environmental change such as democracy movements and more explicit political activism may become less influential (the 'crowding out' problem and presumed 'death of politics', Bartley et al. 2015: 76). While the danger of ethical consumerism - leading to the death of politics - may have been greatly exaggerated (ibid), there remain some concerns as to the political nature of this approach. In particular, whether creating the figure of the 'empowered' consumer really produces collective engagement or whether it rather reproduces neoliberal discourses of individual choice and marketization remains an open question (Clarke et al. 2007: 242).

As McEwan et al. (2017) have shown, abstract moral fair trade discourses, largely centred on consumers in the global North, fail to take into account the situated embeddedness of ethics and moral experiences of producers in their respective locations. Instead, they advocate for a deeper acknowledgement of places and their contexts to "appreciate Fairtrade's relational spatiality that is alive to the ongoing and situated entanglements of materiality, resource allocation and cultural identity" (McEwan et al., 2017: 586). This observation resonates with our analysis of sites of contestation as embedded in different places. At the same time, the hope that public and private regulation together will lead to the amicable introduction of consecutively ever-higher norms and better outcomes for all parties, a view that still prevails in some academic and policy circles, in many instances seems unrealistic. As Alford's (2018) study of South African fruit exporters or Arnold and Hess's (2017) analysis of 'ethical' garment production in Cambodia show, contestation in GPNs is more complex and more confrontational, with fault-lines running through and between different fractions of state, firms and civil society actors. In his neo-Gramscian inspired analysis of South African fruit production, Alford (2018) coins the term "antagonistic governance" to describe the situation of ongoing tensions and dynamics related to broader conflicts of interest of actors. Our case study of contestation in the global fur (fashion) industry provides an example of particularly strong forms of antagonistic actors, where struggles over values do not simply revolve around the social and 
environmental standards of production, but are fought about whether commodification and production should take place under any conditions at all. Ethical values can thus severely challenge particular industries. They can also bring entirely new industries into being, such as the 'animal-free food' industry, where ethics are central to the formation of value and thus to the industry itself. Labgrown meat, for instance, "is about leveraging value from the associated ethics and making them crystallise as the commodity" (Mouat et al. 2019: 153).

While conscientious consumerism entails some problematic features, as outlined above, consumers are not to be equated with the rational, self-interested and atomistic individual envisaged by orthodox economic theory and (neo-)liberalism, and are indeed embedded in social relations that influence and reflect their moral and social values including consideration for (distant) others (Sayer 2003; Barnett et al. 2005). As a collective effort, consumer activism through particular networks and associations such as fair trade movements, consumer boycott groups or animal rights organisations therefore represents an important way to develop a set of values, or valuation regime, with regard to a commodity or production process. It is mobilised to contest an existing value regime as promoted by producers and brands, and which is assumed to be unethical. Levy et al. (2015: 6) elaborate the concept of 'value regimes' as arenas for political contestation where civil society and business interact [...]. Following Gramscian thought, they "propose that value regimes achieve a degree of stability when three inter-related dimensions are aligned: Economic models of value creation and distribution, including processes of production and exchange, mechanisms of valuation, and their associated market structures and business models; Normative and cultural values regarding the moral and social value of products, lifestyles, the natural environment, and labour conditions; and governance mechanisms, representing formal and informal rules, power relations, technical standards, and organizations with authority [...]". To this, we want to add that valuation regimes not only involve business and civil society as constituent groups of actors, but also government and regulatory bodies that co-determine economic models of value creation, normative values and governance mechanisms. Consumer activism therefore not only relates to changing corporate practices and business models but also aims at influencing institutional frameworks, legal systems and regulations through government policy, thus trying to assert selected different values and ethical preferences (Clarke et al. 2007) centred on commodities.

\section{Investigating sites of contestation in global fur networks}

Empirical research of GPNs presents considerable practical challenges (Hess and Yeung 2006), which are compounded if powerful lead firms are not easily recognisable from the outset ${ }^{1}$. The extraordinary difficulty of unravelling a global industry is that its connections and linkages stretch potentially endlessly and connect myriad actors. Some scholars have uncovered these linkages through patient tracing of the travels of individual objects and their relations through space in what has been termed the "follow-the-thing" approach (Cook et al. 2006). Revealing the intricate webs of global worlds of production and the complicated life trajectories of commodities, this approach was used as a tool to de-fetishize commodities through an excavation of their life worlds. In contemporary capitalism, however, Hulme argues, commodity chains have become "unfollowable" due to ever-shifting and non-

\footnotetext{
${ }^{1}$ Recent interventions, aiming for causal inference under the moniker GPN 2.0, have severely limited the types of sectors suitable for global production network analysis: "a global production network necessarily entails the central role of one globally significant lead firm [...]. This lead firm should be clearly identifiable within a particular industry" (Coe and Yeung, 2015: 39-40).
} 
traceable links; more importantly, the uncovering itself has reached limits: "globalised commodity chains no longer have the shock of the new; discovering the sweatshop workers at the end of the chain, while of course valuable, is not surprising enough" (Hulme 2016: 158). She suggests to focus our attention to the "syndromes in gaps" and heighten our "awareness of the gaps in an object's trajectory" (ibid.: 159) through multi-sited ethnographies that uncover the systems behind unfollowable commodities.

A range of scholars have pointed out the need to engage more with the "dark-sides" of global production networks (Coe and Hess 2011), in particular the disconnections and "disarticulations", which form a fundamental part of the organisation of commodity chains (Bair and Werner 2011). Focusing on the gaps, ruptures, breakdowns of production and its ruins, in particular through ethnographies (Ouma 2015; Tsing 2015; Werner, 2015), constitutes an important and thriving field of research. Studying the discursive forging of associations and dissociations, similarly, is able to shed light on what is made to be hidden or out of view from consumers (Ibert et al. 2019). In our attempt to analyse material and discursive dimensions of production, circulation and consumption in an integrated fashion, we decided to focus on select moments and places (constituted by relations stretching outward) through a multi-sited case ethnographic case study. Given our focus on the moments of contestation in production networks of fur, and the multitude of different (non-firm) actors engaged in acts of protest and contestation, we have chosen to focus our attention on key sites. The selected sites constitute crucial nodes within GPNs, from production to consumption, and serve as arenas in which the realisation of value through GPNs is challenged and value(s) are negotiated. To conceptually advance a perspective to enable us to observe construction and contestation of value, we differentiate between four types of sites of contestation: production, regulation, circulation, and consumption. Of course, these sites can overlap in one place; Hong Kong for instance, is a site of fur circulation and consumption. Between 2015 and 2017, we visited select sites of fur GPNs that broadly reflect production, trade and consumption geographies, as well as a site of regulation (Figure 1). These included: a fur farm and a design centre in Denmark; fur wholesale centres in Shenzhen and in Seoul; lobby activities in Brussels' EU quarter; a fur auction in Kopenhagen, fur trade and anti-fur protests during fur fairs in Hong Kong and Milan, and fur consumption in London, Stockholm, Hong Kong, Milan, New York City, and Berlin. Despite persistent inquiries, we were unable to negotiate access to sites of and actors involved in fur dressing and dyeing, involving chemical processing of furs.

\section{[Entre Figure 1 about here]}

As a tandem research team, two of the authors travelled together to the sites, observed and conducted 40 interviews with a range of actors in fur GPNs, including representatives of fur lobby groups, farmers, furriers, fur-designers, as well as animal protection associations, animal rights activists. The joint fieldwork as a tandem research team was an important part of our research design, combining different knowledge backgrounds and perspectives. Whereas one of us had grounding in cultural economy and an interest in the discursive constructions and symbolic value, the other one had a background in tracing material networks and flows, adopting a political-economic perspective. Raising different questions in the interviews and joint discussions, interpretation and writing was crucial for bringing to life a cultural political economy perspective.

Given the controversial nature of the fur industry, most respondents clearly identified as either 'profur' or 'anti-fur' actors. Our interviews focused on understanding the global networks of fur from the 
actors directly involved in the industry and civil society groups that challenge the industry. Beyond interviews and observations in key sites we focused on analysing discourses in print and online media. The interviews were audio-recorded, transcribed and subsequently analysed, together with the fieldwork notes qualitatively focusing on the narratives, negotiations, and the spatial-temporal embeddedness of contestations.

\section{Sites of contestation in global fur networks}

For decades, the commodification of fur has been strongly contested and it remains subject to enduring pressures by animal rights groups of different orientations and operating at different scales. After experiencing a deep crisis following animal rights activism and PETA's (People for the Ethical Treatment of Animals) 'I'd rather go naked than wear fur' campaign in the 1990s, fur has experienced a resurgence. The classic full-fur coat, typically worn as a status-signifier by upper(-middle)-class women in the global North is now only one segment in the booming fur business. No longer limited to luxury consumption designed and produced by traditional furriers, real and faux fur have become integrated into fast-fashion production circuits. Today, fur is a common sight as coyote-trimming on men's outdoor jackets, as colourful pompons attached to mobile phones or bags, or even as fur-lining on sandals. Contemporary fur-fashion addresses a younger consumer-base and has successfully reorientated itself from a niche market into the mainstream fashion industry (Skov 2005; Rantisi 2014).

The fur industry was valued at \$US 40 billion in 2014, according to a PricewaterhouseCooper report commissioned by the International Fur Trade Federation. In contrast to most garments and textiles value chains, the fur sector is not buyer-driven but producer-driven (Skov 2005). The most powerful actors in the fur sector, the 'lead firms', are the Northern European auction houses, Kopenhagen Fur (Denmark) and Saga Furs (Finland). Both are owned by the resource-producers, the respective countries' fur farmers associations. Auction houses fulfil a key function in coordinating the market, collecting individual skins, sorting and grading them and bundling them into larger, standardised batches of different quality-levels. The price of fur skins is mainly related to their quality, which depends on factors such as the type of animal, size, colour, gender, thickness, softness and shininess of the fur. The raw skins are subsequently dressed and dyed with chemicals, similar to leather tanning.

The Eurogroup for Animals functions as an umbrella organisation for many national animal rights groups. Debates, petitions, and protests are organised by animal rights and animal welfare groups in many European countries, to which the fur industry's groups (the International Fur Trade Federation, European Fur Breeders Association, Fur Europe, national groups such as SwissFur, British Fur Trade and Deutsches Pelzinstitut, and, most prominently, the Danish and Finnish fur breeders associations) respond with intensified lobbying, self-certification initiatives, and labels (Fur Europe, 2015).

\subsection{Sites of production}

Sites of production are where intermediate goods are created and/or the assembly of final goods takes place through labour power. In fur GPNs it entails the commodification of fur skins into tradeable resources, their dressing and dyeing, and the production of final garments for sale. As such, sites of production include fur-farms, processing factories for dressing and dyeing, craft garment manufacturing and garment factories. 
The production of fur requires the transformation of the skin of a living fur-bearing animal into a commodity. The predominant share of fur animals, approximately 85 percent, is not hunted or trapped, but farmed and thus is part of agricultural circuits of production. Of these, mink is the most important species, accounting for 80 percent of international trade in fur skins. Other animals include fox, chinchilla, nutria, Finnraccoon (also known as Racoon Dog), and sable (Fur Europe 2015). Pressure by civil society organisations has severely restricted the geographies of fur production, leading to a concentration in a few North-European regions with significant fur-farming clusters in Danish Jutland and Finnish Ostrobothnia. Denmark is the largest producer of mink furs in the world (18.6 million mink skins in 2016) where the sector benefits from tight vertical integration into Danish high-intensity agriculture, for example through access to feed from adjacent fishery and poultry sectors (Christensen 2010).

Clearly, as in other natural resource industries, capitalist circuits of production also engage here in the "permanent struggle to standardise, control and simplify nature" (Baglioni and Campling, 2017: 2446), but are confronted with the limits and constraints to commodifying nature. Biophysical processes and seasonality structure the breeding cycles. Mink has a growth cycle of one year that cannot be accelerated and the animals require cold climate to grow thick fur. Foxes, in contrast, require three years before they are slaughtered and skinned, thus explaining the popularity of mink as a species for fur-framing. Mink are not artificially inseminated, thus the breeding process cannot entirely be controlled. Fur farmers can only respond to market demands (e.g. in terms of colours, length of hair) with a delay of 1.5 to two years.

\section{Fur farm in Sjælland, Denmark}

The farm we visit has around 3000 breeder minks, which is an average size-farm. Breeders speak of fur "harvesting", suggesting non-animal-based agricultural production. Production at the farm is highly-modern and efficiently organised, including computerised distribution of exact amounts of high-protein nutrition read from bar-codes of the cages. Killing is portrayed as relatively humane as it is done on-site and does not involve transport. Farmers stress that animals lose consciousness in a matter of seconds (estimates range from 10 to 30) inside the 'gas box', whereas some animal rights activists link the 'gassing' to the Holocaust (see Figure 2).

\section{[Enter Figure 2 about here]}

Killing, skinning, the cleaning and drying of furs, all taking place in November of each year, are represented as very hands-on, work and experience-intensive proceedings involving multiple steps and technical artefacts. Anti-fur campaigners point at a natural unsuitability of animals like mink for farm-breeding and have broken into fur farms to expose animal mistreatment. After a scandal in 2009, Danish fur breeders began promoting selective openness and transparency, inviting the public into their farms on 'Open Days' to demonstrate their farming practice. The relationship between farmer and animals is actively portrayed as a close and emotional one. 'We live for the animals', the farmer told us near the end of the site visit.

Many of darker sides of production, in particular the dressing and dyeing facilities in Southern and Eastern Europe as well as garment manufacturing firms, predominantly located in China, remained closed to us. Animal rights activists focus on the site of farms to challenge the commodification of animals, in particular through exposing animal cruelty and farm conditions. These involve break-ins 
and the shooting of disconcerting and often shocking revelatory video footages of farms. The fur farms are shown as dark sites of animal suffering and activists aim at closing fur farms, often appealing to the government for regulations and bans.

\subsection{Sites of regulation}

The laws governing what can be legally produced and traded are established at the international, supranational (e.g. European), national and sub-national (e.g. regional or even city) scale, thus including multiscalar regulatory bodies and parliaments. In the case of fur, these relate particularly to the individual fur-producing countries and the European Union. On the international level, the Convention on International Trade in Endangered Species (CITES) treaty of 1973 prohibits the international trade of several endangered species, such as leopards. Beyond this agreement no international regulation restricts the fur trade. At the level of the European Union, regulations prohibit the import and export of seal-, dog- and cat-fur and the use steel-traps. The labelling of fur products is compulsory.

The fur sector is mainly regulated by national legislation on animal welfare standards in agricultural production, which regulate which species can be farmed and under which conditions. Fur-farming is entirely banned in Austria, the United Kingdom, Slovenia and Bulgaria. Legislation has been passed to phase out fur farming in Croatia and Czech Republic (both 2017), Bosnia-Herzegovina (2019), and the Netherlands (2024). Several countries have introduced stricter regulations for fur farming, based on considerations of animal welfare (e.g. raising the minimum size of cages, providing access to swimming and digging opportunities), which have made fur businesses unprofitable and have led to fur farm closures in Switzerland, Sweden and Italy (Fur Europe, 2015). Beyond national legislation, regional legislation at the sub-national scale prohibits fur-farming in several European regions, for instance Wallonia in Belgium. Also, a rescaling of debate to the European Union has taken place, with debates and lobby activities concentrated in Brussels.

EU Quarter, Brussels, Belgium

Policy makers at the EU level are subject to intense lobbying by the fur industry, including the staging of the 2014 exposition "This is Fur" in the European Parliament. The business association Fur Europe spends almost half a million Euro on lobby activities, has three registered lobbyists in Brussels and had six meetings in the past three years with EU representatives, including Ministers of the European Parliament from the main fur exporting countries (https://www.integritywatch.eu/). Most animal right groups' activities (including PETA and Fur Free Alliance) are not listed. Fur Europe takes a moral high-ground for making their activities transparent and criticises animal rights activists for failing to do so, a strategy one observer refers to as "transparency-washing".

To counter pressure for tighter governmental regulation, the fur industry alternatively aims for voluntary standards and controls. The WelFur programme has been rolled out, in which the fur industry seeks collaboration and at the same time visibly associates itself with academic experts in the field of animal welfare research. WelFur is a point-based European animal welfare assessment system for fur farms, differentiated by species. It is modelled after comparable systems established for other animal-industries across Europe. The framework is composed of a set of quantified farm-level indicators across the areas 'good feed', 'good health', 'good housing' and 'good behaviour' which together result in a point score. This score is translated into grades from excellent to inacceptable. 
WelFur is centred on invoking ideas of proven expertise and rationality, thus counter-acting emotional or 'irrational' messages. It also displays an effort in self-regulation which critics perceive as an attempt at pre-empting stricter external regulation - such as the 2009 ban on fox fur farming in Denmark. Both the visible relationships with academic institutions and the objective appeal of a quantified metric invoke an image of professionalism, control and attentiveness. They conceal the fact that conditions which consumers would still find inacceptable can very well persist under this system: As is the nature of a scoring system, grievances in one area can be weighed against benefits in another. The grade 'inacceptable' will only be applied in cases of excessive malpractice. Finally, as a farm-based animal welfare assessment system, WelFur is based on indicators easily applicable - i.e. measurable but also actionable - in the farm setting upon which the creation of exchange value is premised. The system is thus inherently based on practical convenience and will never lead to results that fundamentally question fur farming and the commodification of fur.

In contrast to standards developed in other global industries, such as the textiles industry, in the fur industry, these initiatives are single-issue based around animals and do not take into consideration other criteria frequently benchmarked, including environmental and labour conditions. Labour, however, is always required for the successful transformation of resources into commodities (Baglioni and Campling, 2017). Nowhere in the discourse or the contestations around fur farming have we encountered debates around labour conditions. The focus on animals displaces other debates and makes invisible or dissociates other concerns, usually prevalent in GPNs, including labour and nonanimal related environmental impacts.

\subsection{Sites of Circulation}

Sites of circulation are places where commodities are valuated and exchanged. In the case of fur, these include highly concentrated geographies and temporary sites. The trade of farmed fur skins is organised in a small number of auction houses, often controlled by fur breeder's associations, such as Saga Fur in Finland and Kopenhagen Fur in Denmark. The exchange value of animal pelts depends on the quality and popularity of certain types of fur, which are valuated at the fur auction houses. The circulation of fur products is channeled through wholesale markets and trade fairs, where actors form temporary clusters (Maskell et al. 2006). Given the temporality of these sites of circulation, the spaces of contestation tend to be impermanent and transitory, too.

\section{Kopenhagen Fur Auction House, Glostrup, Denmark}

With five auctions a year and a turnover of 6.3 billion DKK (\$US 997 million) in 2016, Kopenhagen Fur is the world's largest fur auction house. Located at the outskirts of the Danish capital city of Kopenhagen, the large-scale complex of Kopenhagen Fur is an important site for the valuation and circulation of fur and beyond quality assessment, auctioning offers services such as storage and logistics. Fur skins auctioned via Kopenhagen Furs are made traceable through an elaborate system of coding, tagging and information processing. This traceability, however, extends only from farm to auction and back, as its main purpose is to supply breeders with critical data (crucially, on quality gradings and prices fetched in auctions). Raw fur skins are bought in homogenous lots by brokers, who sell them to garment manufacturers. Auction houses control the access to brokers, who in turn only provide extremely limited information on their business practice and do not publicize who their customers are. Respondents in the fur industry estimated that around $50 \%$ of fur skins are used for 
traditional full-fur clothes while the other $50 \%$ are used for branded fashion garments and accessories. Yet, no statistics or tracking systems exist to document through which processing and manufacturing steps fur skins go after auction. The organizational distance enacted by a brokerage system reduces the 'burden of knowledge' for raw fur producers, although arguably technological innovations in auctioning (such as live broadcasting via apps) have reduced brokers' knowledge advantage and brought fur producers and garment manufacturers closer.

A slight majority of brokers bidding at the Copenhagen auction today are Chinese, presumably working for Chinese clients. The branding of "Nordic" fur occurs at the auction, where fur lots quality controlled and sold through the auction (rather than being produced in certain countries) receive Kopenhagen Fur labels in four quality categories: Ivory, Burgundy, Platinum and Purple. The labels are meant to be sown into the final garments and are dispatched through logging into Kopenhagen Furs website. Several of these labels turn up for sale (independently of the fur) on online auctions.

Despite the auction house being a secluded place with a lack of direct contestation, the creation of the 'Origin Assured' (OA) label issued by Scandinavian fur marketing organizations and distributed to manufacturers who buy at their auctions can be seen as a direct reaction to pressures from animal rights groups. The label was intended to signify to consumers that all furs used for a garment come from countries with animal welfare regulations in place. However, publicly disseminated information about the label remained vague about the selection of countries included, the nature of regulations, the minimum standards for receiving the label, their enforcement and verification as well as the agencies tasked with verification. There is no evidence that serious verification steps took place at any time. Animal rights organizations were quick to produce footage of animal mistreatment allegedly obtained in OA countries. By coining and distributing the visually similar counter-label 'Cruelty Assured' in conjunction with abhorred images they successfully dismantled the constructed association and create counter-associations. Nevertheless, the label is still in use. Traditional furriers both in Europe and Hong Kong were found to attach the label to their products and referring to it when asked about the origin of their furs. Key actors in the fur industry such as Kopenhagen Fur, however, have gradually and carefully distanced themselves from the OA label, pointing at the WelFur approach.

97 per cent of Danish mink is exported, predominantly to China and Hong Kong (Hansen 2016). Hong Kong fulfills an important role as a trading site and serves as a design hub, as a target for mainland Chinese tourism (and luxury good shopping), but also as a logistics hub, housing cold storage warehouses where lots identical to the ones auctioned in Copenhagen are kept on stock, thus allowing for instant delivery. Hong Kong hosts the world's biggest fur fair, focusing on fur in branded mass market fashion and the Chinese market.

\section{Hong Kong International Fur and Fashion Fair, Convention and Exhibition Centre, Hong Kong}

Once a year, the international fur industry representatives meet in Hong Kong and showcase the latest fur trends. In February 2016, the fur fair is strikingly little advertised (in contrast to the following Diamond Fair taking place) in the city. The Convention Centre is an open ground floor space with cafés open to the public. Visitors to the exhibition space need badges to enter. On the afternoon of the last day of the fair, security forces set up mobile gates and install tape to close off one of the (several) exits of the fair. Soon after, a group of protesters arrive, carrying "no fur" signs and images of animal carcasses. Some protestors are dressed in animal and skinned animal costumes. The protest is almost 
soundless, safe for a timid call of "no fur". News reporters take pictures and the skinned animal holds the hands of the metal bars that block the exhibition hall, leading to a striking protest image (Figure 2). After about 20 minutes, the protesters move towards one of the many shopping malls. The carefully planned and arranged protests need to be understood within their embedded context of social, political and economic struggles in Hong Kong, including the umbrella revolution.

\section{[Enter Figure 3 about here]}

Campaigners interviewed were rather open in their characterization of the fur industry as a strategic and relatively easy target: 'It is visual', explained a Hong Kong based campaigner (Interview with activist leader, February 2016). Presented during protests and in myriad visual materials, the image of the skinned animal body, along with the gruelling possibility of it being skinned alive leaves a strong impression.

Beyond the key nodes in the fur trade, such as Hong Kong and London, we found unusual spaces of contestation that relate to valuations and capital flows on financial markets, including board rooms of investors. For instance, a small Dutch pension fund has a black list for its investment which includes next to nuclear weapons, mines and cluster ammunition, and employment rights, a fourth category of "animal rights (fur)". This precludes investment into the Burberry Group and Hugo Boss, as well as entire conglomerates (such as LVMH) due to fur-selling brands within the conglomerate (PNO Media, 2012: 39-40).

\subsection{Sites of Consumption}

The sites of consumption are shopping malls, high-streets and shopping districts catering to particular clienteles, including luxury consumption and tourism. Fur has traditionally been sold in fur districts of New York or Frankfurt, clusters of fur craft and sale. Today, most fur is sold in the shopping districts of large cities, including Hong Kong, New York and Paris, which cater to global markets and attract considerable numbers of tourists. The spaces of sale, such as shop-windows and displays, are important elements in making fashion valuable (Crewe 2016). Outside of these shops temporary protest spaces are created, in which (potential) consumers are directly confronted with graphic images of animal suffering.

\section{Fur District, New York City, USA}

Originally located between 26th and 30th Street (around Eighth Avenue and Avenue of the Americas) New York's traditional furrier quarter (also the original site of manufacturing) has been in decline already since the 1980s. The number of furriers has plummeted and the remaining ones south of Penn station have installed heavy double-doors, barred-windows and frequently require ringing a bell before the spaces of consumption open up, possibly installed as a measure not simply against theft but also against animal rights activists. We are greeted with suspicion, when entering the shops with mainly Greek or Asian names that sell almost exclusively fur garments (often at large discounts). The entire district makes a somewhat desolate impression and many empty and 'for-rent' shop-fronts make palpable the stress the traditional fur sector is under.

Beyond the fur district, fur garments are sold in retail shops and appear on the same clothing rails, sometimes visibly labelled, but overall presented together and in identical ways with synthetic fur. The mixed fur and non-fur selling stores, despite the ubiquity of fur products and large sale volumes, 
were much less frequently the target of attack by animal rights activists than specialised furriers. As the private spaces of shopping malls are able to prevent protests, mostly, animal rights groups stand outdoors of main-street stores. The protest use visual graphics, usually of discarded and bloody animal carcasses and the gruesome killing is a central theme. Activists usually do not address the larger fur industry but launch personalised attacks against immoral (female) shoppers. Visibility and media attention are key for the often rather small-scale protests, with top-less or naked women a recurring motif drawing attention.

Rallying supporters behind the anti-fur case is easier than mobilizing consumers against meat, dairy or leather, since fur is not seen as a necessary ingredient in everyday consumption, but rather as an unnecessary luxury. Activists quite openly declare that targeting fur is a strategic move, and that fur is to serve as the beachhead for ending other forms of animal-based production and consumption on the long run. Not surprisingly, the fur industry is quick to brand anti-fur-campaigning as fuelled by class-envy, and styles itself as the defender of the freedom to consume not only fur, but meat, leather and dairy (Interview with industry respondent, July 2016).

In addition, the (wrong) public perception that fur is only consumed by a wealthy minority, makes it easier to rally support against fur than, for instance, meat or leather. However, by attacking the more vulnerable target of fur, animal rights activists hope to lay groundwork for attacks on more widespread animal uses. Wider environmental considerations, although periodically mentioned, are secondary to this rationale. Anti-fur organizations such as PETA only occasionally broach the issue of environmental and human impacts of fur processing, despite the fact that all raw fur skins require dressing, a process similar to leather tanning through which skin and hair are rid of residual fat and made resistant to decomposition. In further steps, fur can be dyed in various colours or otherwise refined. These processes require chemical compounds reaching from extremely acidic to extremely alkaline, can involve toxic heavy metals like bromium and are both water and energy intensive. Dedicated environmental pressure groups such as Greenpeace, who also pick their targets strategically, clearly view fur as a topic for animal rights campaigners and thus do not engage with it.

In response to the contestations around farmed fur alternatives for ethical consumers have sprouted. "Ethical fur" includes a variety of materials, including (i) synthetic fur used for instance by fashion designer Stella McCartney, (ii) "accidental fur" originating from road-kill, or (iii) fur as a by-product of other sectors, all of which are subject to debates around their sustainability and ethicality and tend to invoke the critique of animal rights activists (Kleibert and Müller, 2017). Interestingly, the sites of contestation of fur span beyond the fur sector itself but are used for branding of other, non-related consumer products. Ethical rents emerge not only as a source of marketing a product as green, sustainable, fair or confirming to other societal values and thus commanding a premium price, but CSR strategies can increase the brand reputation, or at least minimize reputational risk and thus increase the value of (non-related) products sold.

Lush store and website "Fighting the Fur Trade"

An interesting space of contestation is the British cosmetics brand Lush, which is primarily known for selling fragrant vegetarian soaps and other beauty products. Their window displays anti-fur signs of the \#MakeFurHistory campaign among the soaps for sale (Figure 4).

[Enter Figure 4 about here] 
The company's website gives more detailed information and accounts of activities, thus contestations occur in physical and online spaces. The firm has sponsored the HK\$80,000 (approx. US\$10,000) newspaper ad of a Hong Kong-based animal rights group to fund a protest against a fur trade show in the city (Interview with activist leader, February 2016). Promoting animal-rights causes (largely unrelated to their business) functions as a means of increasing the firm's image as an ethical producer. The mobilisation of ethics, CSR, is used to create ethical rents and increase the sale in unrelated products.

\section{Conclusions}

Investigating sites of contestation in GPNs has allowed us to shed light on the entangled webs of materially and discursively forged connections and disconnections, which are challenged by antagonistic actors. It has offered us a window into the complexities, contradictions and attempts at ordering of the messy realities of "ethical" values in contemporary capitalism. In our analysis, we have shown how processes of contestation in GPNs of animal-based commodities, in our case fur, play out at different sites of production, circulation and consumption. Our empirical case of global fur production networks certainly represents a particularly strong example of "antagonistic" contestation around the commodification and valuation of living beings. The struggles over (de-)commodification, what constitutes value, and what should and should not be valued, marketised and consumed, involves fur producers, traders, consumers, animal rights activists and other civil society actors.

The findings revealed several under-used or unusual sites of contestations and thus may be used by activists to base their strategies on. For instance, we have shown how effective sites may exist in the field of circulation (including investor's board rooms and auction houses), rather than at the sites of production and consumption, which have so far been the main concerns of activists. Our study may also invite a continued conversation with activist research from a cultural geographic perspective, where creative 'cultural activism' disrupts and reframes value(s) at multiple sites (Cook et al., 2019; see also followthethings.com). We have investigated the struggles of producers as well as consumers and civil society organisations over fur as a commodity by looking at the discourses around fur as either a natural and sustainable product with a considerable symbolic value - a framing driven by producers and the fur fashion business - or as a cruel and unethical product that should have neither use nor exchange value as it violates animal rights and therefore should be banned outright. The latter has led to various forms of protest that articulate in different ways at specific sites and geographies of production, circulation and consumption, with the very materiality of fur as commodity at the centre of conflict. Analysing these sites of contestation and the strategies of various actors to stabilise or impose their economic, normative and governance principles of how valuation regimes ought to be constructed (Levy et al. 2015), we believe, not only utilises but also contributes to a cultural political economy of GPNs by providing a novel methodology of investigating 'ethical' GPNs, contestation and 'political' consumption. Moreover, we have highlighted the dissociations from related struggles around ethical production and consumption, most importantly labour and environmental standards, which have been sidelined in contestations of fur as a product. The question of which (and whose) ethical problems become central in contestations and which ones are sidelined deserve more attention in the future, in particular, when entire industries draw their economic value from ethical claims (Mouat et al., 2019).

Overall, then, our discussion of selective, disparate and sometimes ephemeral sites of contestation shows how material and discursive connections and disconnections are forged by all actors on 
different sides of the conflict around the commodification and valuation of fur. Adding to the idea that global networks of fur are highly "contested fields" (Levy 2008), we have tried to show how they manifest themselves in particular socio-spatial and temporal arrangements and regimes of valuation. Contestations of commodification and valuation of nonhuman species take place in particular sites and at particular times. They are locally embedded but simultaneously its actors are part of translocal, and often transnational, networks. Focusing on sites of contestation, as a methodology, has enabled us to show the socio-spatial embeddedness of contestations that characterise "global" industries. Such an approach has three advantages: first, it offers an avenue for conducting empirical research of global commodities at a time when GPNs have often become too complex and objects have become "unfollowable" (Hulme 2016); second, it enables us to adopt a cultural political economy perspective (Hudson, 2008) by shedding light not only on moments of production and consumption but also the vital stages of circulation; and third, by focusing on the moments of (discursive) struggles of association and dissociation in the process of contestation, this approach may be better able to respond to calls for moving beyond the "inclusionary bias" (Bair and Werner 2011) and shed light on the darker sides of global production. 


\section{References}

Alexander R (2018) Sustainability in global production networks - Introducing the notion of extended supplier networks. Competition \& Change 22(3): 255-273.

Alford M (2018) Antagonistic governance in South African fruit global production networks: a neoGramscian perspective. Global Networks, in press. https://doi.org/10.1111/glob.12223.

Arnold D and Hess M (2017) Governmentalizing Gramsci: Topologies of power and passive revolution in Cambodia's garment production network, Environment and Planning A 49(10): 21832202.

Baglioni E and Campling L (2017) Natural resource industries as global value chains: Frontiers, fetishism, labour and the state. Environment and Planning A 49(11), 2437-2456.

Bair J (2019) Dialectics of dissociation. Dialogues in Human Geography 9(1): 68-72.

Bair J and Palpacuer F (2015) CSR beyond the corporation: contested governance in global value chains. Global Networks 15(1): 1-19.

Bair J and Werner M (2011) Commodity chains and the uneven geographies of global capitalism: A disarticulations perspective. Environment and Planning A 43(5): 988-997.

Barrientos S, Gereffi G and Rossi A (2011) Economic and social upgrading in global production networks: A new paradigm for a changing world. International Labour Review 150(3-4): 319-340.

Bartley T, Koos S, Samel H, Setrini G and Summers N (2015) Looking behind the Label: Global Industries and the Conscientious Consumer. Bloomington \& Indianapolis: Indiana University Press.

Barnett C, Cloke PC, and Malpass A (2005) Consuming ethics: articulating the subjects and spaces of ethical consumption. Antipode 37: 23-45.

Christensen, J L (2010) Low-tech, high-performing clusters in knowledge-based economies. Conference Paper, DRUID Summer Conference 16-18 June, London.

Clarke N, Barnett C, Cloke P and Malpass A (2007) Globalising the consumer: Doing politics in an ethical register. Political Geography 26(3), 231-249.

Coe N M and Hess M (2011) Local and regional development: A global production networks approach. In: Pike A, Rodriguez-Pose A and Tomaney J (eds.) Handbook of Local and Regional Development. London: Routledge, pp. 128-138.

Coe N M, Dicken P and Hess M (2008) Global Production Networks: realizing the potential, Journal of Economic Geography 8: 271-295.

Coe N M and Yeung H W-C (2015) Global Production Networks. Theorizing Economic Development in an Interconnected World. Oxford: Oxford University Press. 
Coe, N M and Yeung H W-C (2019) Global production networks: mapping recent conceptual developments. Journal of Economic Geography 19(4): 775-801. Collard R-C and Dempsey J (2013) Life for sale? The politics of lively commodities. Environment and Planning A 45(11): 2682-2699.

Cook et al I (2006) Geographies of food: following. Progress in Human Geography 30(5): 655-666.

Cook et al I (2019) A new vocabulary for cultural-economic geography? Dialogues in Human Geography 9(1): 83-87.

Cook I and Crang P (1996) The world on a plate: Culinary culture, displacement and geographical knowledges. Journal of Material Culture 1(2): 131-153.

Crang, M, and Hughes, A (2015) Globalizing ethical consumption. Geoforum 67: 131-134.

Crewe L (2016) Placing fashion: Art, space, display and the building of luxury fashion markets through retail design. Progress in Human Geography 40(4): 511-529.

DeMarchi V, Di Maria E and Ponte S (2013) The greening of global value chains: Insights from the furniture industry. Competition \& Change 17 (4): 299-318.

Fur Europe (2015) Annual Report 2014: Innovating Heritage Responsibly. Brussels: Fur Europe.

Goger A (2013) The making of a 'business case' for environmental upgrading: Sri Lanka's ecofactories. Geoforum 47: 73-83.

Hansen H O (2016) The Danish Fur Industry: Structure, Competitiveness and International Position. Copenhagen: Djøf Publishing.

Havice E and Campling L (2017) Where chain governance and environmental governance meet: Interfirm strategies in the canned tuna global value chain. Economic Geography 93(3), 292-313.

Henderson J, Dicken P, Hess M, Coe N M and Yeung H W-c (2002) Global production networks and the analysis of economic development. Review of International Political Economy 9 (3): 436-64.

Hess M and Yeung H W-c (2006) Whither Global Production Networks in Economic Geography? Past, Present, and Future. Environment and Planning A 38(7): 1193-1204.

Hudson R (2008) Cultural political economy meets global production networks: a productive meeting? Journal of Economic Geography 8: 421-440.

Hughes A, McEwan, C and Bek, D (2015) Mobilizing the ethical consumer in South Africa. Geoforum 67: $148-157$.

Hughes A, Buttle M and Wrigley N (2008) Global production networks, ethical campaigning, and the embeddedness of responsible governance. Journal of Economic Geography 8: 345-367.

Hulme A (2016) Following the (unfollowable) thing: Methodological considerations in the era of high globalization. Cultural Geographies 24(1): 157-160.

Ibert O, Hess M, Kleibert J M, Müller F C and Power D (2019) Geographies of dissociation: Value creation, 'dark' places and 'missing' links. Dialogues in Human Geography 9: 43-63. 
Irarrázaval F and Bustos-Gallardo B (2019) Global Salmon Networks: Unpacking Ecological Contradictions at the Production Stage. Economic Geography 95(2): 159-178

Kay K and Kenney-Lazar M (2018) Value in capitalist natures: An emerging framework. Dialogues in Human Geography 7(3): 295-309.

Kleibert J M and Müller F C (2017) Femininity and the rise of 'ethical fur'. Journal of Consumer Ethics 1(2): 55-62.

Levy D (2008) Political contestation in global production networks. Academy of Management Review 33(4): 943-963.

Levy D, Reinecke J and Manning S (2015) The political dynamics of sustainable coffee: contested value regimes and the transformation of sustainability. Journal of Management Studies 53(3): 364401.

Maskell P, Bathelt $\mathrm{H}$ and Malmberg A (2006) Building global knowledge pipelines: The role of temporary clusters. European Planning Studies 14(8), 997-1013.

McEwan C, Hughes A and Bek D (2017) Fairtrade, place and moral economy: Between abstract ethical discourse and the moral experience of Northern Cape farmers. Environment and Planning $A$ 49(3), 572-591.

Mouat, M. J., Prince, R., \& Roche, M. M. (2019) Making value out of ethics: The emerging economic geography of lab-grown meat and other animal-free food products. Economic Geography 95(2), 136158.

Nadvi K (2008) Global standards, global governance and the organization of global value chains. Journal of Economic Geography 8 (3): 323-343.

Ouma S (2015) Assembling Export Markets: The Making and Unmaking of Global Food Connections in West Africa. Malden and Oxford: Wiley-Blackwell.

Pensionsfonds PNO Media (2012) Jaarverslag: Verantwoord Beleggen. Available at: https://www.pnomedia.nl/Portals/O/Downloads/Jaarverslag/Jaarverslag 2012 PNOMedia.pdf

Pike A (2015) Origination. The Geographies of Brands and Branding. Malden/Oxford: WileyBlackwell.

Ponte S, Poulsen R and Lister J (2017) Business and Transnational Environmental Governance. In: Rasche A, Morsing M and Moon J (eds.). Corporate Social Responsibility. Strategy, Communication, Governance. Cambridge: Cambridge University Press, 427-450.

Rantisi N M (2014) Exploring the role of industry intermediaries in the construction of 'local pipelines': The case of the Montreal fur garment cluster and the rise of fur-fashion connections. Journal of Economic Geography 14: 955-971.

Richey L A (2019) Eclipsed by the halo: 'Helping' brands through dissociation. Dialogues in Human Geography 9(1): 78-82. 
Richey L A and Ponte S (2011) Brand Aid: Shopping Well to Save the World. Minneapolis: University of Minnesota Press.

Sayer A (2003) (De) commodification, consumer culture, and moral economy. Environment and Planning D: Society and Space 21(3), 341-357.

Skov L (2005) The return of the fur coat: a commodity chain perspective. Current Sociology 53(1): 932.

South China Morning Post (2019) Fur trade in Hong Kong: animal rights activists call on government to ban industry in city during annual protest. Available online at:

https://www.scmp.com/news/hong-kong/health-environment/article/2186548/animal-rightsactivists-call-hong-kong-government.

Tsing A L (2015) The Mushroom at the End of the World: On the Possibility of Life in Capitalist Ruins. Princeton: Princeton University Press.

Werner, M. (2015). Global Displacements: The Making of Uneven Development in the Caribbean. Malden, Oxford and Chichester: John Wiley \& Sons.

Werner M (2018) Geographies of production I: Global production and uneven development. Progress in Human Geography. In press. https://doi.org/10.1177/0309132518760095.

Willmott $\mathrm{H}$ (2010) Creating 'value' beyond the point of production: branding, financialization and market capitalization. Organization 17(5): 517-542. 